\title{
Ecological risk and enrichment of potentially toxic elements in the soil and eroded sediment in an organic vineyard (Tokaj Nagy Hill, Hungary)
}

\author{
Nhung Thi Ha Pham (D) Izabella Babcsányi · Andrea Farsang
}

Received: 8 March 2021/Accepted: 16 August 2021/Published online: 3 September 2021

(C) The Author(s) 2021

\begin{abstract}
Potentially toxic elements (PTEs), such as $\mathrm{Cu}, \mathrm{Zn}, \mathrm{Pb}, \mathrm{Ni}, \mathrm{Cr}$, and $\mathrm{Co}$, can accumulate in vineyard soils due to repeated uses of inorganic pesticides and chemical or organic fertilizers. In sloping vineyards, PTEs can also be moved by soil erosion resulting in their accumulation in low-energy zones within the landscape, adversely affecting the soil environment. Our study evaluated the ecological risk related to the pseudo-total and bioavailable PTE contents $(\mathrm{Zn}, \mathrm{Pb}$, $\mathrm{Co}, \mathrm{Ni}, \mathrm{Cr}$, and $\mathrm{Cu}$ ) in the soil and eroded sediment samples from an organic vineyard in Tokaj (NE Hungary). The contamination status and the ecological risk of target PTEs were assessed by calculating the contamination factor, the pollution load index, the ecological risk factor, and the ecological risk index. The median pollution load indices of $1.15,1.81$, and 1.10 for the topsoil, the sediments, and the subsoil, respectively, demonstrate a moderate multi-element contamination case in the organic vineyard. Target PTEs tented to show increased concentrations in eroded sediments with the highest enrichment ratio
\end{abstract}

N. T. H. Pham ( $₫)$ · I. Babcsányi · A. Farsang

Department of Geoinformatics, Physical and

Environmental Geography, University of Szeged,

Egyetem u. 2-6, Szeged 6722, Hungary

e-mail: hanhung@geo.u-szeged.hu

\section{N. T. H. Pham}

Faculty of Environmental Sciences, University of Science, Vietnam National University, Hanoi, 334 Nguyen Trai

Street, Thanh Xuan District, Hanoi, Vietnam
(3.36) observed for $\mathrm{Cu}(\mathrm{Cu}$ in the sediment/Cu in the topsoil), revealing a preferential movement of $\mathrm{Cu}$-rich soil particles by overland flow. Moreover, PTEs were present in the sediments in more bioavailable forms (except $\mathrm{Ni}, \mathrm{Cr}$ ), assessed by an extraction procedure with EDTA. The ecological risk index $(<90)$ based on the studied PTEs showed an overall low ecological risk in the vineyard. Copper was the predominant factor of the ecological risk. Moreover, the highest ecological risk factor (24.6) observed for the bioavailable $\mathrm{Cu}$ content in an eroded sediment sample (representing $82 \%$ of the total ecological risk) shows that $\mathrm{Cu}$ accumulation in sloping vineyards is an ecological risk, particularly in the sedimentation zones. The high proportions of bioavailable $\mathrm{Cu}$ in the vineyard's soil represent an increasing ecological risk over time, related to repeated treatments of vine plants with $\mathrm{Cu}$-based pesticides.

Keywords Bioavailability - Ecological risk assessment · Potentially toxic element · Vineyard soil . Sediment $\cdot$ Soil erosion

\section{Introduction}

Agricultural production is influenced by natural drivers such as soil, topography, climate, and landscape (Li \& Zhou, 2015; Schaller et al., 2018). These 
factors play a key role in cultivation culture and product quality, especially in sustainable agriculture (Schaller et al., 2018). In addition, the "terroir," which is the combined effect of several local factors, including the soil, has a substantial role in determining the grape quality and wine sensory properties (Czigány et al., 2020; Ferrretti, 2019; Qi et al., 2019). However, agricultural activities are a primary source of potentially toxic elements (PTEs) in cultivated soils, generating permanent pollution of large areas (Chen et al., 2015; Li et al., 2015). Particularly, in the vineyards, soil pollution with PTEs from the continuous use of cupric fungicides and fertilizers is a predominant issue (Preston et al., 2016). With the long-term use of chemical fertilizers, fungicides, and organic byproducts, viticulture can exert a considerable risk of soil contamination that may ultimately impact product quality (Mirzaei et al., 2019; Preston et al., 2016). Fertilizers supply non-negligible quantities of PTEs, such as $\mathrm{Cu}, \mathrm{Zn}$, and $\mathrm{Ni}$, that are essential micronutrients for plant growth. Yet, their increased contents in the cultivated soils may reach toxicity thresholds, exceeding the optimal range for plants and soil microorganisms (Dhaliwal et al., 2019). The intensive use of fertilizers and copper-based fungicides have already induced superabundance of PTEs (such as $\mathrm{Cu}, \mathrm{Zn}, \mathrm{Cd}, \mathrm{Pb}, \mathrm{Cr}, \mathrm{Ni}, \mathrm{Hg}$, and As) in many vineyard soils (Chen et al., 2015; Liang et al., 2015; Mirzaei et al., 2019). Specific accumulation patterns and bioavailability of PTEs have been assessed in previous studies for evaluating the contamination level, the environmental pollution risk, and the toxicity of PTEs to crops (Borgese et al., 2013; Liu et al., 2005; Nunes et al., 2014; Sipos 2004; Violante et al., 2010). However, organic vineyards have been rarely targeted in those studies. Therefore, further research on PTEs and the associated ecological risk is necessary to supply information on the sustainability of current organic farming practices in vineyards.

Erosion has been indicated as one of the major threats that affect agricultural soils (Biddoccu et al., 2016). In particular, hilly vineyards are easily subject to soil erosion, depending on the soil management system, and have the highest measured soil losses compared to rainfed cereals, olives, eucalyptus plantation, or scrubland (Biddoccu et al., 2016; Kosmas et al., 1997; Novara et al., 2011). Tillage or weed control with herbicides usually used in vineyards leave the bare soil exposed to rainfall and runoff during all or part of the year (Biddoccu et al., 2020). As a result, in the sloping vineyard, soil erosion and cultural practices drive the spatial distribution of macro-and micronutrients in the soil (Chevigny et al., 2014; Czigány et al., 2020). The spatial distribution of the fertilizer- and pesticide-derived PTEs in vineyard soils is also affected (Manaljav et al., 2021). Soil erosion and redeposition of PTE-rich sediment particles increase the risk of contamination of non-target environments (He et al., 2004; Ribolzi et al., 2002). Indeed, vineyard soils undergo wash-off during intense rainfall events, especially in steep areas, which may raise environmental and ecological concerns locally (in the soil) and off-site when reaching vulnerable aquatic environments (Martínez-Casasnovas \& Ramos, 2006; Koulouri \& Giourga, 2007). Hence, the impact of soil erosion on the distribution and transport of PTEs should be carefully evaluated based on assessing both the total and the bioavailable PTE contents in the soil and eroded sediments in vineyards.

In recent years, ecological risk concerns associated with the accumulation of PTEs have arisen and become an environmental burden (Arfaeinia et al., 2019; Milićević et al., 2018; Mirzaei et al., 2019). The ecological risk of PTEs calculated based on contamination factors and biological toxicity factors has been widely used for soil and sediment contamination investigations (Canuto et al., 2013; Hakanson, 1980). Also, for a better understanding of the PTE-related risks, their bioavailable concentrations should be considered. Therefore, in our study, pollution load and ecological risk indices are calculated based on the pseudo-total and the bioavailable contents of PTEs. In vineyards subject to erosion, PTEs can be significantly relocated and accumulated in low-energy zones of the landscape. Hence, the enrichment and ecological risks of PTEs should also be examined in eroded sediments. In some previous works (Liang et al., 2015; Milićević et al., 2018; Mirlean et al., 2007; Mirzaei et al., 2019; Romíc et al., 2004), the PTEs selected in our work (Zn, $\mathrm{Pb}, \mathrm{Co}, \mathrm{Ni}, \mathrm{Cr}$, and $\mathrm{Cu}$ ) were indicated as potential soil pollutants with ecological risk concerns. Thus, we aimed to assess the pseudo-total and bioavailable fractions of $\mathrm{Zn}, \mathrm{Pb}, \mathrm{Co}, \mathrm{Ni}, \mathrm{Cr}$, and $\mathrm{Cu}$ in the soil and eroded sediments collected in an organic vineyard on the hillslope of the Tokaj Nagy Hill, a part of the Tokaj-Hegyalja Wine Region (NE Hungary). The specific objectives of the study are (1) to evaluate 
relationships between soil properties $(\mathrm{pH}$, soil organic matter (SOM), carbonate content, and soil texture) and the pseudo-total and bioavailable contents of target PTEs, (2) to determine the contamination status and enrichment of selected PTEs in the soil and eroded sediments, and (3) to assess the ecological risk of target PTEs.

\section{Material and methods}

Study area and sample collection

The study area is part of the Hétszőlö vineyard situated at the south-facing hillslopes of Tokaj Nagy Hill (NE Hungary). Tokaj Nagy Hill is one of the easternmost members of the inner Carpathian volcanic range in Hungary (Lóczy, 2015; Molnár et al., 2010; Zelenka et al., 2004; Szepesi et al., 2018). The primary parent material is a late Miocene stratovolcano, built up of pyroxene dacite lava flows and subordinate pyroxene dacite tuffs (Harangi \& Lenkey, 2007; Novák et al., 2014; Zelenka et al., 2004). Loess deposits cover volcanic rocks of the Tokaj Nagy Hill with their thickness ranging from a few centimeters to $20 \mathrm{~m}$ (Kerényi, 1994; Lóczy, 2015; Novák et al., 2014). An open-pit quarry (dacite stone quarry) abandoned in the 1980s is situated at $\sim 500 \mathrm{~m}$ from the studied site. The climate is humid continental, characterized by cold winters and warm summers. The mean annual precipitation varies between 590 and $610 \mathrm{~mm}$, with a clear maximum value (360 $\mathrm{mm}$ falls) in the summer months (Dövényi et al., 2010). The mean and the maximum rainfall intensity during the year of study (2019) were $1.3 \mathrm{~mm} / \mathrm{h}$ and $27.8 \mathrm{~mm} / \mathrm{h}$. The mean annual temperature is $8.5^{\circ} \mathrm{C}$ at the summit and reaches almost $10{ }^{\circ} \mathrm{C}$ at the base of the Tokaj Nagy Hill (Novák et al., 2014).

The study site (Fig. 1) is a 1.8 ha vineyard plot with a mean slope of $8^{\circ}$ and a hillslope length of $270 \mathrm{~m}$. A mixture of grass and herbaceous plants cover the vine inter-rows for limiting soil erosion. The soil is tilled $(0-20 \mathrm{~cm})$ biannually in the inter-rows; meanwhile, tillage is done twice a year underneath the vine rows. Mowing is practiced to control weed, and no herbicides are used. The vineyard is managed according to the guidelines of organic farming. For years, fresh cattle manure was used at a dose of $0.3 \mathrm{t} / \mathrm{ha}$ every 3-4 years for soil fertilization. For the last ten years, the local vinegrowers have applied cattle manure pellets. Treatments with $\mathrm{Cu}$-based fungicides are regularly done in a typical $4 \mathrm{~kg} / \mathrm{ha} /$ year dose (metallic $\mathrm{Cu}$ ). We suppose that most of the $\mathrm{Cu}$-pesticide applications have taken place over the past 28 years since replanting the vineyard in 1993. The soil in the vineyard is a Calcaric Regosol (Siltic, Ochric) according to the World Reference Base for Soil Resources (2014). The soil in the vineyard is weakly developed due to the intense soil erosion that prevents the formation of apparent diagnostic horizons. The soilforming parent material is loess.

In March 2019, the topsoil $(<20 \mathrm{~cm}$ layers: $0-10 \mathrm{~cm}$ and $10-20 \mathrm{~cm})$ and subsoil $(>20 \mathrm{~cm}$ layers: 20-30 cm; 30-40 cm; 60-80 cm; 120-140 cm; and 180-200 cm) samples (21 soil samples) were collected at three locations in the vineyard using a hand auger (Fig. 1). Subsoil samples collected from boreholes at 180-200 cm depth are considered as the parent material devoid of impacts from plant protection treatments and not reaching the dacite base rock. At the same time, six sediment traps were deployed along the main slope. Additionally, a composite topsoil sample from $0-10 \mathrm{~cm}$ soil layer was collected from the local forested site as a reference soil (not being impacted by vine-growing). In May 2019, eroded sediment samples from the traps were collected along with six topsoil samples $(0-20 \mathrm{~cm})$ near each trap (Fig. 1). During the sample collection period (one week), the average precipitation depth was $2.58 \mathrm{~mm}$ per rainfall event; the mean rainfall intensity was $1.55 \mathrm{~mm} / \mathrm{h}$, and the maximum intensity was $5.5 \mathrm{~mm} /$ h. The total rainfall depth was $15.5 \mathrm{~mm}$. Rainfall data are continuously recorded on-site within the area of the Hétszőlö vineyard using a rain gauge set up (Type BCU LITE2, Boeras Ltd., Hungary).

Sample treatment and analyses

The collected soil samples were air-dried, while the eroded sediment samples were oven-dried at $80{ }^{\circ} \mathrm{C}$. All samples were disaggregated in a mortar with a pestle and then sieved to pass through a 2-mm sieve. The hygroscopic moisture of each sample was determined at $105{ }^{\circ} \mathrm{C}$ in the oven for $24 \mathrm{~h}$ (overnight). The soil $\mathrm{pH}$ (d.w.) was measured in a mixture (1:2.5) of soil-deionized water using a digital $\mathrm{pH}$ meter (Inolab pH 720) (MSZ-08-0206-2, 1978) ( \pm 0.05). The SOM content was analyzed by a UV-VIS 


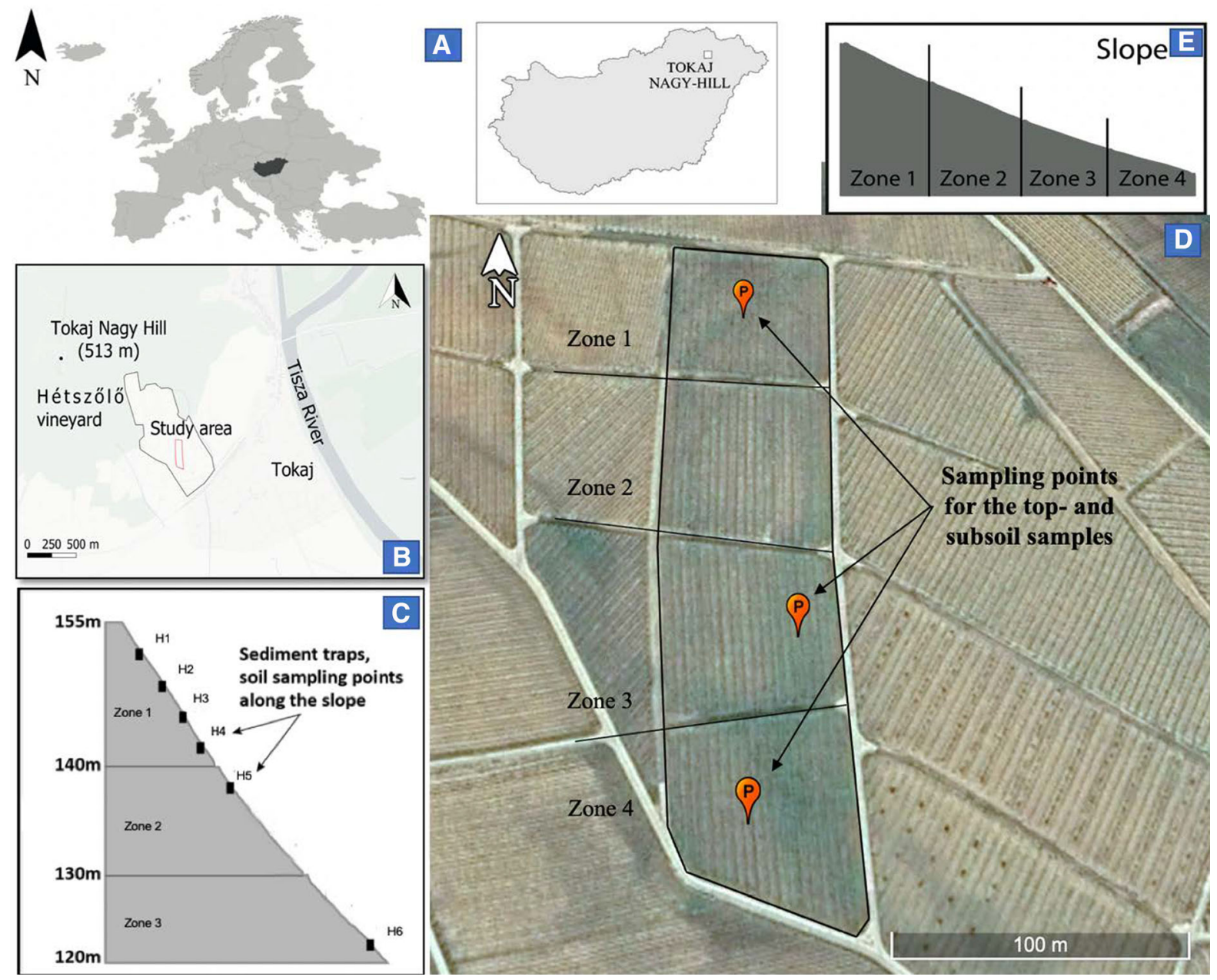

Fig. 1 A Location of the study vineyard, situated in the winegrowing region of Tokaj-Hegyalja (NE Hungary); B The intermediate map for Tokaj; $\mathbf{C}$ and $\mathbf{E}$ The slope profiles and the

spectrophotometer (a type Spectronic Helios- $\gamma$, Thermo Fisher Scientific), following $\mathrm{H}_{2} \mathrm{SO}_{4}$-aided oxidation of the organic matter with $0.33 \mathrm{M} \mathrm{K}_{2} \mathrm{Cr}_{2} \mathrm{O}_{7}$ (MSZ-21470-52, 1983) ( $\pm 2 \%$ ). The carbonate content (in percentage of dry matter weight, $\pm 8 \%$ ) was determined using a calcimeter according to the Scheibler method using $10 \% \mathrm{HCl}$ solution for the reaction (Bojar et al., 2020). The values of the plasticity index according to Arany (Arany Plasticity Index) are used to identify the soil texture following the Hungarian Standard-MSZ-08-0205, 1978. The method consists of determining the amount $\left(\mathrm{cm}^{3}\right)$ of deionized water added to $100 \mathrm{~g}$ of air-dry soil sample until reaching the upper limit of its plasticity. The particle-size distribution was determined by the position of sediment traps and soil sampling along the main slope; D Sampling points for the top- and subsoil

pipette method following treatment with $0.1 \mathrm{M}$ sodium pyrophosphate (MSZ-08-0205, 1978).

For the pseudo-total PTE analysis ( $\mathrm{Zn}, \mathrm{Pb}, \mathrm{Co}, \mathrm{Ni}$, $\mathrm{Cr}$, and $\mathrm{Cu}$ ), samples were finely ground in an agate ball mill (for soil samples) or in a mortar with a pestle (for sediment samples) to pass through a $250 \mu \mathrm{m}$ sieve. Then, $0.5 \mathrm{~g}$ sample material was weighed into a PFA vessel and $7 \mathrm{ml}$ aqua regia $\left(\mathrm{HNO}_{3} / \mathrm{HCl}=1: 3=\right.$ $1.75 \mathrm{ml}: 5.25 \mathrm{ml})$ was added. Clean acids were applied (Normatom ${ }^{\circledR}$ for trace metal analysis, VWR Chemicals) for digestion and standard dilution. Samples were digested in a microwave oven (Anton Paar Multiwave 3000) as described elsewhere (Szolnoki \& Farsang, 2013). Concentrations of PTE in digested samples were determined by an inductively coupled 
plasma optical emission spectrometer (ICP-OES) (Optima 7000 DV, PerkinElmer) (with $\pm 10 \%$ uncertainty), using yttrium as an internal standard.

The bioavailable fraction of PTEs ( $\mathrm{Zn}, \mathrm{Pb}, \mathrm{Co}, \mathrm{Ni}$, $\mathrm{Cr}$, and $\mathrm{Cu}$ ) was quantified using an extraction procedure with a strong chelating agent $(0.05 \mathrm{M}$ $\mathrm{Na}_{2}$-EDTA) (Carter \& Gregorich, 2007). All centrifuge tubes were acid-washed and rinsed with purified $0.05 \mathrm{M} \mathrm{Na}_{2}$-EDTA followed by a complete ultrapure water rinse. For the extraction procedure, $1.0 \mathrm{~g}$ sample material was weighed in a $50 \mathrm{ml}$ centrifuge tube and $25 \mathrm{ml}$ of purified $0.05 \mathrm{M} \mathrm{Na}_{2}$ EDTA was added. Samples were rotated in an endover-end shaker (Stuart SP3 Rotator) (at $15 \mathrm{rpm}$ for $1 \mathrm{~h}$ ), centrifuged (at $2500 \mathrm{~g}$ for $20 \mathrm{~min}$ ), filtered (at $0.45 \mu \mathrm{m}$ ), and then kept at $4{ }^{\circ} \mathrm{C}$ until ICP analysis (as described by Carter \& Gregorich, 2007). Before determining bioavailable PTE concentrations by ICP-OES, all samples were diluted 20-times with ultrapure water. Calibration standards were prepared in the same matrix as the diluted extract solution.

Soil contamination and risk assessment indices

\section{Contamination factor $(C f)$}

Assessing the degree of contamination by a given PTE is performed by comparing the pollutant element concentration with unpolluted reference material as background concentration (Antoniadis et al., 2017; Mirzaei et al., 2019; Rinklebe et al., 2019). Thence, in our study, Cf was calculated by dividing the content of an individual PTE in the vineyard soil/sediment by its background concentration in the local forest as the reference soil. The equation is as follows:

$\mathrm{Cf}=\frac{\mathrm{C}_{\mathrm{s}}}{\mathrm{C}_{\mathrm{RefS}}}$

(Antoniadis et al., 2017a, b, 2019; Rinklebe et al., 2019). where $C_{\mathrm{s}}$ is an element content $(\mathrm{mg} / \mathrm{kg}) ; \mathrm{C}_{\mathrm{RefS}}$ is the reference concentration of the element in the local forest soil. The classification of the contamination factor is described in 4 levels (Hakanson, 1980; Islam et al., 2015): low contamination $(\mathrm{Cf}<1)$; moderate contamination $(1 \leq \mathrm{Cf}<3)$; considerable contamination $(3 \leq \mathrm{Cf}<6)$; high contamination $(6 \leq \mathrm{Cf})$.

\section{Pollution load index (PLI)}

The PLI was applied here for evaluating the overall pollution degree of soils and sediments considering all target PTEs. PLI (unitless) was calculated by multiplying the Cf of each element (Antoniadis et al., 2019; Mirzaei et al., 2019) following Eq. 2:

$\mathrm{PLI}=\sqrt[\mathrm{n}]{\mathrm{Cf}_{1} \times \mathrm{Cf}_{2} \times \mathrm{Cf}_{3} \times \ldots \times \mathrm{Cf}_{\mathrm{n}}}$

where $\mathrm{Cf}_{1}$ to $\mathrm{Cf}_{\mathrm{n}}$ are the contamination factors of the first to the $\mathrm{n}^{\text {th }}$ PTE in the vineyard soil/sediment. The degree of contamination based on the PLI is described in 5 levels (Mirzaei et al., 2019): non-pollution $(\mathrm{PLI}=0)$; non to moderate pollution $(0<\mathrm{PLI} \leq 1)$; moderate pollution $(1<\mathrm{PLI} \leq 2)$; moderate to high pollution $(2<\mathrm{PLI} \leq 3)$; high pollution $(3<\mathrm{PLI})$.

\section{Ecological risk factor (Ei)}

Hakanson (1980) first used the ecological risk factor to evaluate the ecological risk of pollutants in sediments. Thereafter, authors have widely included these indices in their studies investigating the environmental consequences of soil contamination (Arfaeinia et al., 2019; Islam et al., 2015; Mirzaei et al., 2019; Sun et al., 2010). The ecological risk factor (Ei) is applied to assess the ecological risk of an individual metal according to the Hakanson ecological risk index, as follows:

$\mathrm{Ei}=\mathrm{Cf}_{\mathrm{i}} \times \mathrm{T}_{\mathrm{i}}$

where $\mathrm{Cf}_{\mathrm{i}}$ is the single PTE contamination factor (calculated by Eq. 1) and $T_{i}$ is the biological toxicity factor of an individual target PTE. Based on the recommendations in Luo et al., 2007, standard response coefficients $\left(T_{i}\right)$ for the toxicity of the target PTEs are as follows: $\mathrm{Zn}=1, \mathrm{~Pb}=\mathrm{Co}=\mathrm{Cu}=5$, $\mathrm{Ni}=6$, and $\mathrm{Cr}=2$. These values were also used in our research.

The ecological risk index (ERI) is estimated according to Eq. 4 to evaluate the overall ecological risk of all studied PTEs (Islam et al., 2015; Mirzaei et al., 2019).

$\mathrm{ERI}=\sum_{i=1}^{6} E i(i=1-6)$

where $\mathrm{Ei}$ is the ecological risk factor for each individual PTE involved in the study. 
The ecological risk is grouped into 5 categories for the Eis and 4 for the ERI values (Chen et al., 2015; Islam et al., 2015; Liu et al., 2014):

Ei $<40$ : Low ecological risk; $40 \leq \mathrm{Ei}<80$ : Moderate ecological risk; $80 \leq \mathrm{Ei}<160$ : Considerable ecological risk; $160 \leq \mathrm{Ei}<320$ : High ecological risk; $320<$ Ei: Very high ecological risk.

ERI < 90: Low risk; $90 \leq$ ERI $<190$ : Moderate risk; $190 \leq \mathrm{ERI}<380$ : Considerable risk; $380 \leq$ ERI: High risk.

\section{Enrichment ratio (ER)}

To compare the concentrations of the studied PTEs in the eroded sediments with those in the topsoils $(<20 \mathrm{~cm}$ depth), enrichment ratios $(\mathrm{ER}=$ element content in the sediment over that in the topsoil) were used (Farsang et al., 2012; Farsang \& Barta, 2004; Fernández-Calviño et al., 2012).

\section{Statistical analysis}

The relationships between the top- and subsoil characteristics and the PTE concentration data were explored using the Spearman rank correlation test. The significance level was set at $p<0.05$. One-way analysis of variance (ANOVA) was used to test differences among means in the top- and subsoil parameters. Descriptive statistical analysis of the target parameters was performed using IBM SPSS software (SPSS Inc., 2009).

\section{Results and discussion}

\section{Soil properties}

The statistics of measured parameters of the vineyard topsoil $(0-20 \mathrm{~cm})$ and subsoil $(>20 \mathrm{~cm})$, such as $\mathrm{pH}$, soil texture, carbonate, and soil organic matter (SOM) contents, are presented in Table 1. The soil parameters did not vary significantly between the top- and subsoil layers, except for the SOM content. The topsoils in the studied vineyard are characterized by a poor SOM content $(1.75 \pm 0.51 \%$ in the topsoil), further decreasing downwards in the profile $(0.99 \pm 0.40 \%$ in the subsoil). The soil was moderately alkaline ( $\mathrm{pH}$ ranging from 7.92 to 8.27) owing to its carbonate content that varies from 3.4 to $6.2 \%$. The Arany Plasticity Index showed that the soil texture was a sandy loam without any marked difference between the topsoil and the subsoil. According to the particle-size distribution, both the top- and subsoil have silty loam textural characteristics with slightly lower clay content in the topsoil (Table 1). Soil erosion probably resulted in losses of the fine soil particles from the soil surface, hence the clay content got slightly depleted in the topsoil over time (Biswas et al., 2018; Udom et al., 2018).

Potentially toxic elements in the studied vineyard soil and eroded sediments

The soil-bound PTE contents in the vineyard top- and subsoil are summarized in Fig. 2. Topsoil median contents of $\mathrm{Zn}$ (64.3 in the top- and $51.8 \mathrm{mg} / \mathrm{kg}$ in the subsoil) and $\mathrm{Cu}$ (58.5 in the top- and $28.3 \mathrm{mg} / \mathrm{kg}$ in the subsoil) were higher than their median subsoil contents. However, Ni (29.1 in the top- and $37.7 \mathrm{mg} /$ $\mathrm{kg}$ in the subsoil) and $\mathrm{Cr}$ (37.0 in the top- and $55.6 \mathrm{mg} /$ $\mathrm{kg}$ in the subsoil) showed opposite trends. The pseudototal contents of $\mathrm{Pb}$ (11.1 in the top- and $10.3 \mathrm{mg} / \mathrm{kg}$ in the subsoil) and Co (8.8 in the top- and $9.0 \mathrm{mg} / \mathrm{kg}$ in the subsoil) did not differ significantly. The higher concentration of $\mathrm{Zn}$ and $\mathrm{Cu}$ in the topsoil indicated their enrichment in the vineyard soil. Treatments with Zn-containing fertilizers are regularly done in the vineyard, spreading an annual Zn dose of approximately $30 \mathrm{~g} / \mathrm{ha}$. Alkaline soils are often devoid of adequate Zn levels (Fernández-Calviño et al., 2012); hence, foliar fertilizers are commonly used for preventing $\mathrm{Zn}$ deficiency in crops. We further compared the measured levels with the pollution limit value (B) for soils and sediments figuring in Hungarian standards (Joint Decree No. 6/2009. (IV. 14) KvVM-EüM-FVM, 2009). Zinc, Pb, and Co contents were by far lower than the (B) limit value, as follows: $\mathrm{Zn}(64.3$ vs $200 \mathrm{mg} / \mathrm{kg}), \mathrm{Pb}$ (11.1 vs $100 \mathrm{mg} / \mathrm{kg}$ ), and Co ( 8.8 vs $30 \mathrm{mg} / \mathrm{kg}$ ). Although the $\mathrm{Cu}$ contents were lower than the pollution limit value (B) of $75 \mathrm{mg} / \mathrm{kg}$, a clear $\mathrm{Cu}$ enrichment can be highlighted in the topsoil. Copper accumulation in the topsoil is an increasing problem in conventional and organic vineyards too. Indeed, the average $\mathrm{Cu}$ content $(54.5 \mathrm{mg} / \mathrm{kg})$ detected in the vineyard topsoil in Tokaj is comparable with that in vineyards within the 25 member states of the European Union $(49.26 \mathrm{mg} / \mathrm{kg}$ ) and noticeably higher 
Table 1 Descriptive statistics of soil parameters in the studied vineyard top$(0-20 \mathrm{~cm}$ depth) and subsoil $(>20 \mathrm{~cm}$ depth)

\section{SOM (\%) $\quad$ pH $\quad \mathrm{CaCO}_{3}(\%) \quad$ Arany Plasticity Index $\quad$ Clay $\% \quad$ Silt $\% \quad$ Sand $\%$}

Topsoil $(N=12)$

\begin{tabular}{llllllll} 
Mean & 1.75 & 8.10 & 4.3 & 34 & 17 & 69 & 14 \\
Median & 1.88 & 8.12 & 4.3 & 34 & 16 & 70 & 13 \\
Min & 0.72 & 7.92 & 3.4 & 32 & 11 & 58 & 6 \\
Max & 2.37 & 8.27 & 5.5 & 37 & 20 & 75 & 26 \\
SD & 0.51 & 0.13 & 0.7 & 1 & 3 & 5 & 6 \\
Subsoil $(N=15)$ & & & & & & \\
Mean & 0.99 & 8.17 & 4.5 & 34 & 19 & 68 & 13 \\
Median & 0.96 & 8.14 & 4.6 & 34 & 19 & 68 & 13 \\
Min & 0.37 & 7.85 & 3.3 & 32 & 14 & 60 & 8 \\
Max & 1.52 & 8.52 & 6.2 & 36 & 26 & 75 & 25 \\
SD & 0.40 & 0.19 & 0.8 & 1 & 4 & 4 & 5 \\
\hline
\end{tabular}
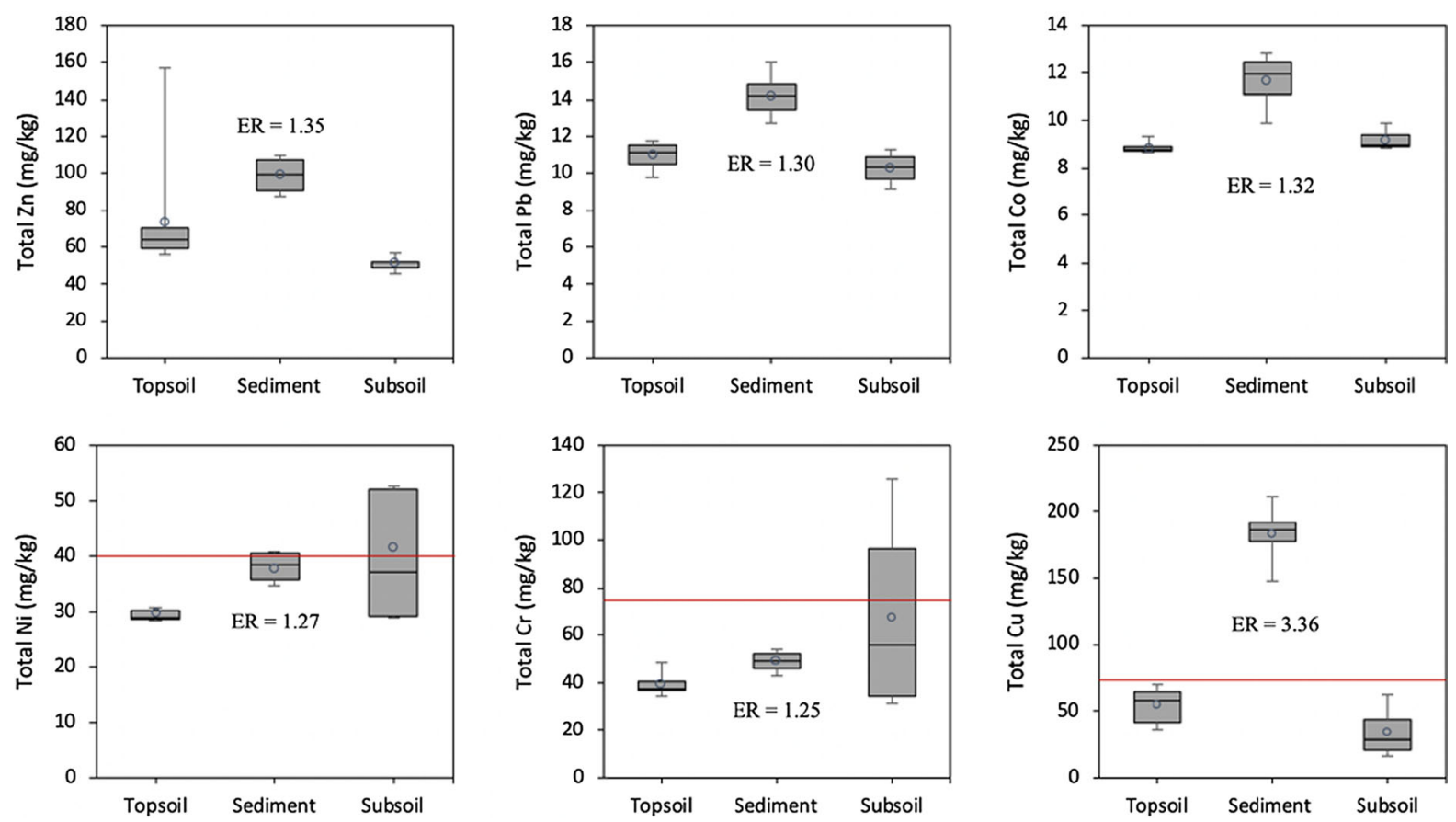

Fig. 2 Pseudo-total PTEs contents $(\mathrm{mg} / \mathrm{kg}$ ) in the top$(0-20 \mathrm{~cm})$ and subsoil $(>20 \mathrm{~cm})$ and the sediment in the vineyard in Tokaj. ER stands for the average of enrichment

ratios (ER) in sediments compared to the topsoil. The red line represents the pollution limit values (B) for soils and sediments according to Hungarian standards

compared to the overall average $\mathrm{Cu}$ concentration of $16.85 \mathrm{mg} / \mathrm{kg}$ in European soils (Ballabio et al., 2018).

Significant differences in $\mathrm{Ni}$ and $\mathrm{Cr}$ contents can be highlighted between the examined soil layers. Higher values in the subsoil (Fig. 2) at the $30-40 \mathrm{~cm}$ soil layer (Ni: $63.1 \mathrm{mg} / \mathrm{kg}$ and $\mathrm{Cr}: 125.5 \mathrm{mg} / \mathrm{kg}$ ) suggest past accumulation. Increased $\mathrm{Ni}$ and $\mathrm{Cr}$ concentrations in specific subsoil layers exceed the pollution limit values in Hungarian standards ( $\mathrm{Ni}: 40 \mathrm{mg} / \mathrm{kg}$ and $\mathrm{Cr}$ : $75 \mathrm{mg} / \mathrm{kg}$ ) (Fig. 2). The spreading of organic fertilizers (for at least 27 years starting from the replanting of the vineyard in 1993) can be a plausible reason, as repeated applications of fresh manure, manure compost, and more recently, manure pellets may significantly increase $\mathrm{Ni}$ and $\mathrm{Cr}$ contents in cultivated soils (Barakat et al., 2016; Gong et al., 2019). Elevated 
concentrations of $\mathrm{Cr}$ and $\mathrm{Ni}$ observed at depths of $30-40 \mathrm{~cm}$, where the plant roots are probably denser (according to Berlanas et al., 2019), may also pose a potential risk of toxicity, especially when replanting with young vine plants (Romić et al., 2004, Lago-Vila et al., 2015). However, those contents are still lower than the toxicity thresholds $(200 \mathrm{mg} / \mathrm{kg}$ for $\mathrm{Cr}$ and $100 \mathrm{mg} / \mathrm{kg}$ for $\mathrm{Ni}$ ) based on previous ecological risk assessment studies (MEF, 2007; Toth et al., 2016). Also, the high subsoil concentrations (at the soil depth of $30-40 \mathrm{~cm}$ ) of $\mathrm{Ni}$ and $\mathrm{Cr}$ can be derived from the weathering of the dacite base rock (Grove et al., 2004) or the dust depositions during the extraction of the dacite rocks in the nearby Binét quarry. The quarry abandoned in the 1980s can be a plausible source of the neighboring vineyard's elevated $\mathrm{Ni}$ and $\mathrm{Cr}$ contents.

Correlation analysis revealed significant positive relationships between the $\mathrm{Zn}, \mathrm{Pb}, \mathrm{Cu}$ and the $\mathrm{SOM}$ contents (Table 2). The SOM content can play a dominant role in the vertical distribution of $\mathrm{Zn}, \mathrm{Cu}$ and $\mathrm{Pb}$. Higher contents of $\mathrm{Cu}, \mathrm{Zn}$, and $\mathrm{Pb}$ tend to prevail in soils rich in SOM compared to those with a poor SOM content (Rinklebe et al., 2019; Shaheen et al.,
2017). The soil $\mathrm{pH}$ and the carbonate content are seemingly insignificant sources of variation for the soil-bound PTE contents in the studied vineyard. However, the lability of PTEs depends on the carbonate and the soil $\mathrm{pH}$ (Bradl, 2004) that are therefore important parameters in assessing PTEs. A significant positive relationship was observed between $\mathrm{Cu}$ and the Arany Plasticity Index and the silt percentage that confirms the affinity of $\mathrm{Cu}$ to fine-grained soil fractions, such as silt (Besnard et al., 2001; Brunetto et al., 2016; Fernández-Calviño et al., 2008, 2012; Rinklebe et al., 2019). In contrast, $\mathrm{Zn}$ and $\mathrm{Cu}$ showed negative correlation with the clay content. This negative relationship can be explained by the frequent fungicide and fertilizer applications which mainly increase the $\mathrm{Cu}$ and $\mathrm{Zn}$ contents in the soil surface, slightly depleted in its clay fraction compared to the subsoil (Brunetto et al., 2014). In some previous works, PTEs were also strongly associated with Fe-Al oxides (bounded and/or occluded) exhibiting a high surface area (Rinklebe et al., 2019; Scheinost, 2005). Indeed, the relationship between $\mathrm{Ni}$ and $\mathrm{Cr}$ contents and total $\mathrm{Fe}$ and $\mathrm{Al}$ in the vineyard soil in Tokaj indicates their association with $\mathrm{Fe}$ and $\mathrm{Al}$ oxides, as
Table 2 Spearman's correlation matrix comparing $\mathrm{pH}$, soil organic matter (SOM), carbonate content, Arany Plasticity Index, and particle-size distribution with the examined PTE contents in all soil sampled layers, and separately in the topsoil (0-20 cm depth) and in the subsoil (>20 cm depth)

*Significant at the level of $p<0.05$

$* *$ Significant at the level of $p<0.01$

\begin{tabular}{|c|c|c|c|c|c|c|c|}
\hline & SOM & $\mathrm{pH}$ & $\mathrm{CaCO}_{3}$ & Arany Plasticity Index & Clay & Silt & Sand \\
\hline \multicolumn{8}{|c|}{ All soil layers } \\
\hline $\mathrm{Zn}$ & $0.95 * *$ & -0.01 & -0.28 & 0.46 & $-0.53^{*}$ & 0.24 & 0.30 \\
\hline $\mathrm{Pb}$ & $0.64 * *$ & -0.28 & -0.30 & 0.24 & -0.31 & -0.09 & $0.50 *$ \\
\hline $\mathrm{Co}$ & -0.48 & 0.00 & 0.10 & 0.01 & $0.55^{*}$ & 0.01 & $-0.50^{*}$ \\
\hline $\mathrm{Ni}$ & -0.48 & -0.20 & 0.12 & -0.46 & 0.13 & -0.29 & -0.00 \\
\hline $\mathrm{Cr}$ & -0.29 & -0.17 & -0.19 & -0.39 & 0.00 & -0.21 & 0.03 \\
\hline $\mathrm{Cu}$ & $0.77 * *$ & -0.07 & -0.05 & 0.48 & $-0.51^{*}$ & 0.19 & 0.33 \\
\hline \multicolumn{8}{|c|}{ Topsoil } \\
\hline $\mathrm{Zn}$ & $0.78 * *$ & -0.02 & -0.18 & 0.38 & -0.46 & 0.26 & -0.12 \\
\hline $\mathrm{Pb}$ & 0.40 & -0.27 & -0.17 & 0.21 & -0.44 & -0.02 & 0.20 \\
\hline Co & -0.01 & 0.38 & 0.40 & 0.60 & 0.04 & $0.65^{*}$ & -0.62 \\
\hline $\mathrm{Ni}$ & -0.40 & -0.12 & 0.40 & 0.05 & -0.03 & -0.15 & 0.16 \\
\hline $\mathrm{Cr}$ & -0.39 & -0.23 & -0.34 & -0.12 & 0.04 & -0.42 & 0.32 \\
\hline $\mathrm{Cu}$ & 0.44 & -0.23 & 0.21 & $0.71 *$ & -0.48 & 0.27 & -0.13 \\
\hline \multicolumn{8}{|c|}{ Subsoil } \\
\hline $\mathrm{Zn}$ & $0.96 * *$ & -0.63 & -0.64 & 0.07 & 0.00 & -0.29 & 0.43 \\
\hline $\mathrm{Pb}$ & $0.94 * *$ & -0.56 & -0.70 & -0.07 & 0.12 & -0.57 & 0.65 \\
\hline Co & 0.29 & -0.62 & $-.835^{*}$ & -0.29 & 0.65 & -0.56 & -0.06 \\
\hline $\mathrm{Ni}$ & -0.23 & -0.15 & -0.13 & $-0.79 *$ & -0.06 & -0.27 & .073 \\
\hline $\mathrm{Cr}$ & -0.25 & -0.20 & -0.13 & $-0.82 *$ & -0.02 & -0.31 & 0.09 \\
\hline $\mathrm{Cu}$ & $0.86^{*}$ & -0.38 & -0.40 & -0.46 & -0.25 & -0.61 & $0.90 * *$ \\
\hline
\end{tabular}


described in another forthcoming paper of our group (Pham et al., forthcoming paper, unpulished ).

Enrichment ratios were applied to assess PTE enrichment in eroded sediments compared to the vineyard topsoil $(<20 \mathrm{~cm}$ depth) (Fig. 2). Zinc $(\mathrm{ER}=1.35), \mathrm{Pb}(\mathrm{ER}=1.30), \mathrm{Co} \quad(\mathrm{ER}=1.32), \mathrm{Ni}$ $(\mathrm{ER}=1.27)$, and $\mathrm{Cr}(\mathrm{ER}=1.25)$ exhibited significantly higher contents in the sediments compared to the vineyard topsoil. The pseudo-total concentration of $\mathrm{Cu}$ ranging between 148.1 and $211.5 \mathrm{mg} / \mathrm{kg}$ was substantially greater than its topsoil levels (range: $36.5-70.0 \mathrm{mg} / \mathrm{kg}$ ). Accordingly, the highest ER was also observed for $\mathrm{Cu}$ (3.36). Elevated concentrations of PTEs are often detected in sediments moved by rainfall-runoff in sloping vineyards (Devi et al., 2018; Komárek et al., 2010). The preferential association of PTEs with the organic-rich sediments $(3.14 \pm 0.23 \%)$ can explain their enrichment. Erosion and subsequent sedimentation of organic-rich suspended material and the post-deposition association of PTEs with organicrich deposits within the low-energy zones of the terrain may be an important process driving the heterogeneous distribution of such elements in the topsoil (Rinklebe \& Shaheen, 2014; Rinklebe et al., 2019). In addition, the eroded sediments are suggested to be enriched in silt-sized particles and depleted in coarser particles (Fernández-Calviño et al., 2008). Such fine-grained particles are generally considered an important contributor to the accumulation of PTEs in soils and sediments. The high contents of $\mathrm{Cu}$ in eroded sediments indicated that an appreciable part of anthropogenic $\mathrm{Cu}$ from treatments with organic amendments (fresh cattle manure, cattle manure pellets) and $\mathrm{Cu}$-based fungicides might be moved and eventually exported off-site during rainfall-runoff events, as earlier observed in vineyard areas (Babcsányi et al., 2016; Besnard et al., 2001; FernándezCalviño et al., 2008; Ribolzi et al., 2002). Therefore, a plausible risk of the translocation of PTE-polluted soil from vineyards into adjacent areas and surface water environments raises ecological risk concerns.

Bioavailable contents of PTEs in the vineyard soil and sediments

The total PTE content is insufficient for an adequate environmental risk assessment because the mobility of these elements depends on their binding forms (Fernández-Calviño et al., 2012; Rinklebe \& Shaheen,
2014; Szolnoki and Farsang 2013). Meanwhile, the bioavailability of PTEs has been used as a useful tool for evaluating the environmental pollution risk and toxicity to crops (Borgese et al., 2013; Nunes et al., 2014; Violante et al., 2010). Typically, the EDTA extracted PTE contents (marked with $\mathrm{X}_{\mathrm{E}}$ ) in the sediments were higher than those in the vineyard topand subsoil, except for Co and Ni (Fig. 3). Copper showed substantial lability in the eroded sediments compared to the vineyard soils (Fig. 3). In addition, the important proportions of bioavailable $\mathrm{Cu}$ in the topsoil, sediment, and subsoil (with bioavailable ratios of $48 \%, 63 \%$, and $37 \%$, respectively) indicated its weak binding (Table 3). At the same time, EDTA salt was formerly found to overestimate $\mathrm{Cu}_{\mathrm{E}}$ content, especially in eroded sediments with a high organic matter content, due to its capability of dissolving high molecular weight organic compounds and of sequestering the $\mathrm{Cu}$ from the organic matter binding sites (McBride et al., 1998). Similarly, high bioavailability ratios of $\mathrm{Pb}$ and $\mathrm{Co}$ in the vineyard soil and sediment indicated their lability, particularly in the sediments (66\%) and subsoil (53\%) for $\mathrm{Pb}$, and in the top- and subsoil for Co (33 and 45\%) (Table 3). Therefore, assessment of $\mathrm{Pb}$-associated ecological risk is also required for vineyards (especially for children) (Rinklebe et al,. 2019; Tirima et al., 2016). Cobalt has received so far little attention in assessing PTEassociated ecological risks, yet Co is broadly considered as an element in the high-risk category (BarrioParra et al., 2017). Median EDTA-extracted contents of $\mathrm{Co}$ and $\mathrm{Ni}$ in the subsoil were higher than those in the sediment (Co: 4.0 vs $2.5 \mathrm{mg} / \mathrm{kg}$ and $\mathrm{Ni}: 4.5$ vs $2.2 \mathrm{mg} / \mathrm{kg}$ ), indicating the mobilization of particles bearing less bioavailable $\mathrm{Ni}$ and $\mathrm{Co}$. The $\mathrm{Cr}_{\mathrm{E}}$ content in the sediments was markedly higher than that in the top- and subsoil, which contrasted its lower total content in the sediment. Overall, bioavailability ratios of $\mathrm{Ni}$ and $\mathrm{Cr}$ in both vineyard soil and sediments were low, accounting for $9 \%$ and $1 \%$, respectively (Table 3).

The $\mathrm{Zn}_{\mathrm{E}}$ contents in the topsoil showed a great range of variation (range $1.9-72.3 \mathrm{mg} / \mathrm{kg}$ ) and represented on average $17 \%$ of the pseudo-total $\mathrm{Zn}$. Bioavailable fractions of $\mathrm{Zn}$ were either not detected or negligible in the subsoil. A higher median $\mathrm{Zn}_{\mathrm{E}}$ content was found in the sediment $(21.6 \mathrm{mg} / \mathrm{kg})$ compared to the vineyard topsoil $(7.3 \mathrm{mg} / \mathrm{kg})$, the former accounting for $22 \%$ of the total $\mathrm{Zn}$ contents 

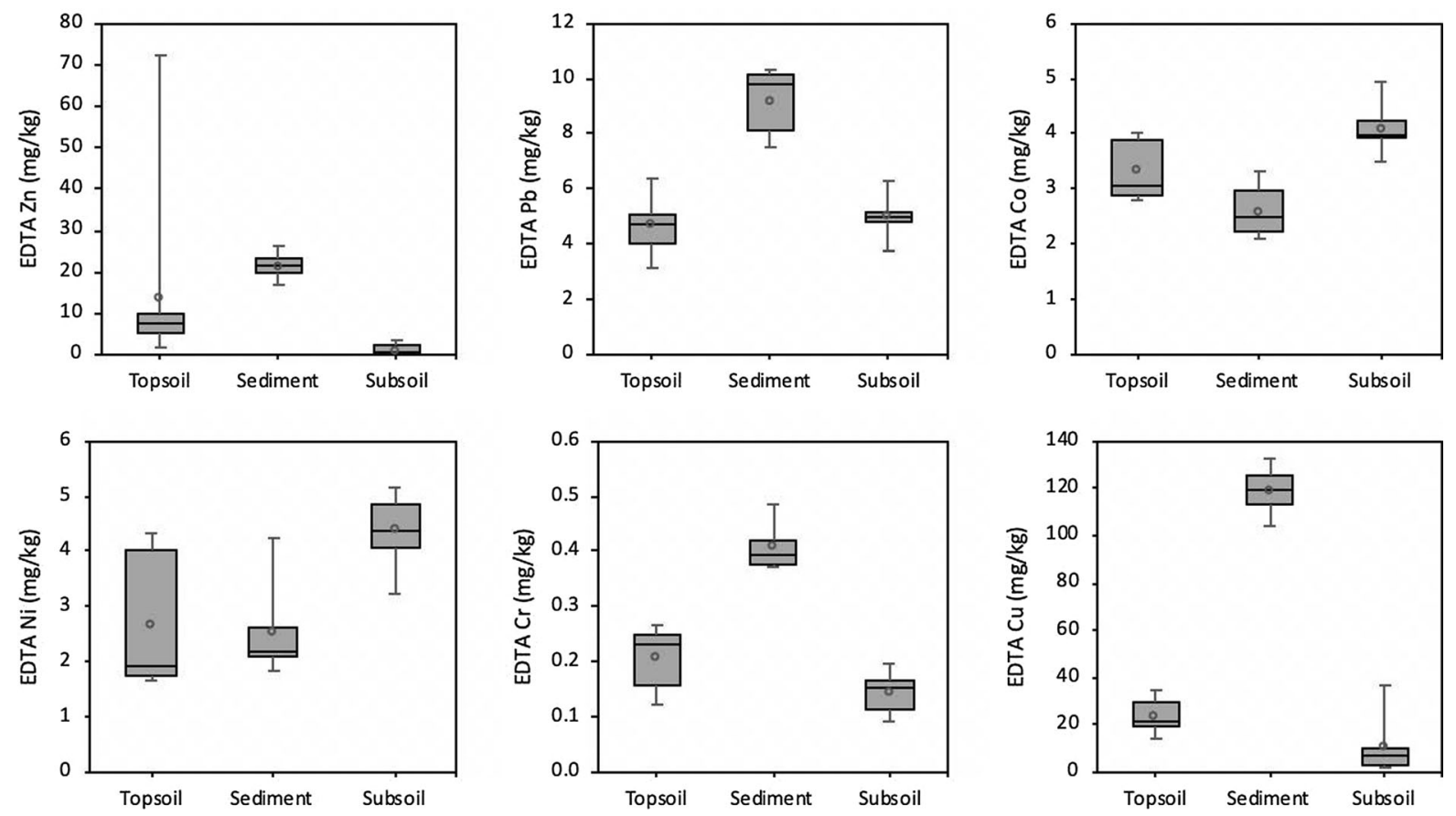

Fig. 3 Bioavailable contents of the target PTEs $(\mathrm{mg} / \mathrm{kg})$ in the top- $(0-20 \mathrm{~cm})$, subsoil $(>20 \mathrm{~cm})$, and the eroded sediments in the studied vineyard

Table 3 Median of bioavailability ratio* (\%) of target PTEs in the soil and sediments

\begin{tabular}{lllllll}
\hline & $\mathrm{Zn}$ & $\mathrm{Pb}$ & $\mathrm{Co}$ & $\mathrm{Ni}$ & $\mathrm{Cr}$ & $\mathrm{Cu}$ \\
\hline Topsoil & 13 & 39 & 33 & 6 & 1 & 48 \\
Sediment & 22 & 66 & 21 & 6 & 1 & 63 \\
Subsoil & 7 & 53 & 45 & 9 & 0 & 37
\end{tabular}

*Bioavailable Ratio $(\%)=$ (Bioavailable metal fraction/ pseudo-total metal concentration in sample material) $\times 100$ (Alibrahim \& Williams, 2016; Kashem \& Singh, 2001)]

(Table 3). Zinc was reported as an element presenting low mobility in alkaline soils, mainly bound to and incorporated into minerals (Antoniadis et al., 2017; Brunetto et al., 2014, 2016; Duplay et al., 2014). Likewise, $\mathrm{Zn}$ in eroded sediments showed similar geochemical partitioning mainly detected in the residual and organically bound fractions (Canuto et al., 2013; Fernández-Calviño et al., 2012).

Similarly to the total PTE contents, the soil $\mathrm{pH}$ was not a significant source of variation for their bioavailable proportion in the soil. On the other hand, the SOM content strongly influenced the EDTA extracted contents of target PTEs (Table 4). A positive correlation with the SOM content for $\mathrm{Zn}_{\mathrm{E}}$ and $\mathrm{Cu}_{\mathrm{E}}$ may be driven by the soil $\mathrm{pH}$ of the studied vineyard soils. Indeed, the alkaline $\mathrm{pH}$ in former researches promoted organic matter solubilization and hence the release of complexed $\mathrm{Cu}$ from soils (Brunetto et al., 2016; Fernández-Calviño et al., 2008), while Zn release presumably occurred through its release from $\mathrm{Al}$ and Fe oxyhydroxides (Fernández-Calviño et al., 2012). On the other hand, the bioavailable contents of Co and $\mathrm{Ni}$ were negatively correlated with the SOM in soils in line with their lower EDTA-extracted contents in the runoff-transported sediments. Overall, the low mobility of $\mathrm{Co}$ and $\mathrm{Ni}$ in the studied alkaline soils and a lack of SOM-related enrichment in sediments during erosive rainfall events further corroborate their geogenic origin.

Soil contamination indices

The PTE-based contamination factors (Cfs) in the sediment were higher than those in the vineyard soil, except for $\mathrm{Ni}$ and $\mathrm{Cr}$ (Fig. 4). The median Cfs in the sediments for $\mathrm{Zn}$ (1.8), Co (1.3), Ni (1.4), and Cr (1.4) imply a moderate contamination level. The high $\mathrm{Cfs}$ 
Table 4 Spearman's correlation matrix of $\mathrm{pH}$, soil organic matter (SOM), carbonate content, Arany Plasticity Index, and particle-size distribution compared with the EDTA extracted PTE contents (marked with $\mathrm{X}_{\mathrm{E}}$ ) in all soil layers, and separately in the topsoil (0-20 cm depth) and in the subsoil $(>20 \mathrm{~cm}$ depth)

* Significant at the level of $p<0.05$

**Significant at the level of $p<0.01$

\begin{tabular}{|c|c|c|c|c|c|c|c|}
\hline & SOM & $\mathrm{pH}$ & $\mathrm{CaCO}_{3}$ & Arany Plasticity Index & Clay & Silt & Sand \\
\hline \multicolumn{8}{|c|}{ All soil layers } \\
\hline $\mathrm{Zn}_{\mathrm{E}}$ & $0.84 * *$ & -0.39 & -0.29 & 0.24 & $-0.49 *$ & 0.01 & 0.41 \\
\hline $\mathrm{Pb}_{\mathrm{E}}$ & -0.13 & -0.28 & -0.09 & -0.18 & -0.20 & $-0.78 * *$ & $0.78 * *$ \\
\hline $\mathrm{Co}_{\mathrm{E}}$ & $-0.66^{* *}$ & -0.09 & -0.09 & $-0.45^{*}$ & 0.44 & $-0.46^{*}$ & 0.11 \\
\hline $\mathrm{Ni}_{\mathrm{E}}$ & $-0.55^{*}$ & -0.14 & -0.21 & -0.35 & 0.42 & $-0.62 * *$ & 0.26 \\
\hline $\mathrm{Cr}_{\mathrm{E}}$ & $0.53 *$ & -0.11 & 0.19 & 0.36 & 0.05 & 0.25 & -0.24 \\
\hline $\mathrm{Cu}_{\mathrm{E}}$ & $0.78 * *$ & -0.34 & -0.12 & $0.48^{*}$ & $-0.54 *$ & -0.01 & 0.40 \\
\hline \multicolumn{8}{|c|}{ Topsoil } \\
\hline $\mathrm{Zn}_{\mathrm{E}}$ & $0.77 * *$ & -0.61 & -0.52 & 0.27 & -0.42 & 0.14 & 0.07 \\
\hline $\mathrm{Pb}_{\mathrm{E}}$ & -0.38 & -0.46 & -0.10 & -0.03 & -0.22 & $-0.79 * *$ & $0.83 * *$ \\
\hline $\mathrm{Co}_{\mathrm{E}}$ & $-0.72 *$ & -0.01 & 0.29 & -0.10 & 0.01 & $-0.64 *$ & $0.67 *$ \\
\hline $\mathrm{Ni}_{\mathrm{E}}$ & $-0.71 *$ & 0.02 & 0.28 & -0.25 & 0.15 & $-0.70 *$ & $0.67 *$ \\
\hline $\mathrm{Cr}_{\mathrm{E}}$ & $0.72 *$ & -0.17 & 0.03 & 0.46 & 0.15 & $0.67 *$ & -0.58 \\
\hline $\mathrm{Cu}_{\mathrm{E}}$ & 0.56 & -0.16 & 0.06 & 0.52 & -0.41 & 0.60 & -0.31 \\
\hline \multicolumn{8}{|c|}{ Subsoil } \\
\hline $\mathrm{Zn}_{\mathrm{E}}$ & $0.64 *$ & -0.35 & -0.27 & -0.27 & -0.30 & $-0.81 * *$ & $0.77 * *$ \\
\hline $\mathrm{Pb}_{\mathrm{E}}$ & 0.58 & -0.28 & -0.20 & -0.18 & -0.44 & $-0.74 *$ & $0.78 * *$ \\
\hline $\mathrm{Co}_{\mathrm{E}}$ & -0.03 & -0.36 & -0.60 & $-0.70^{*}$ & 0.42 & -0.04 & -0.14 \\
\hline $\mathrm{Ni}_{\mathrm{E}}$ & 0.26 & -0.57 & $-0.85^{* *}$ & -0.38 & 0.34 & -0.33 & 0.20 \\
\hline $\mathrm{Cr}_{\mathrm{E}}$ & 0.28 & 0.07 & 0.39 & 0.00 & 0.14 & -0.36 & 0.00 \\
\hline $\mathrm{Cu}_{\mathrm{E}}$ & $0.78 * *$ & -0.42 & -0.44 & 0.03 & -0.23 & $-0.87 * *$ & $0.82 * *$ \\
\hline
\end{tabular}
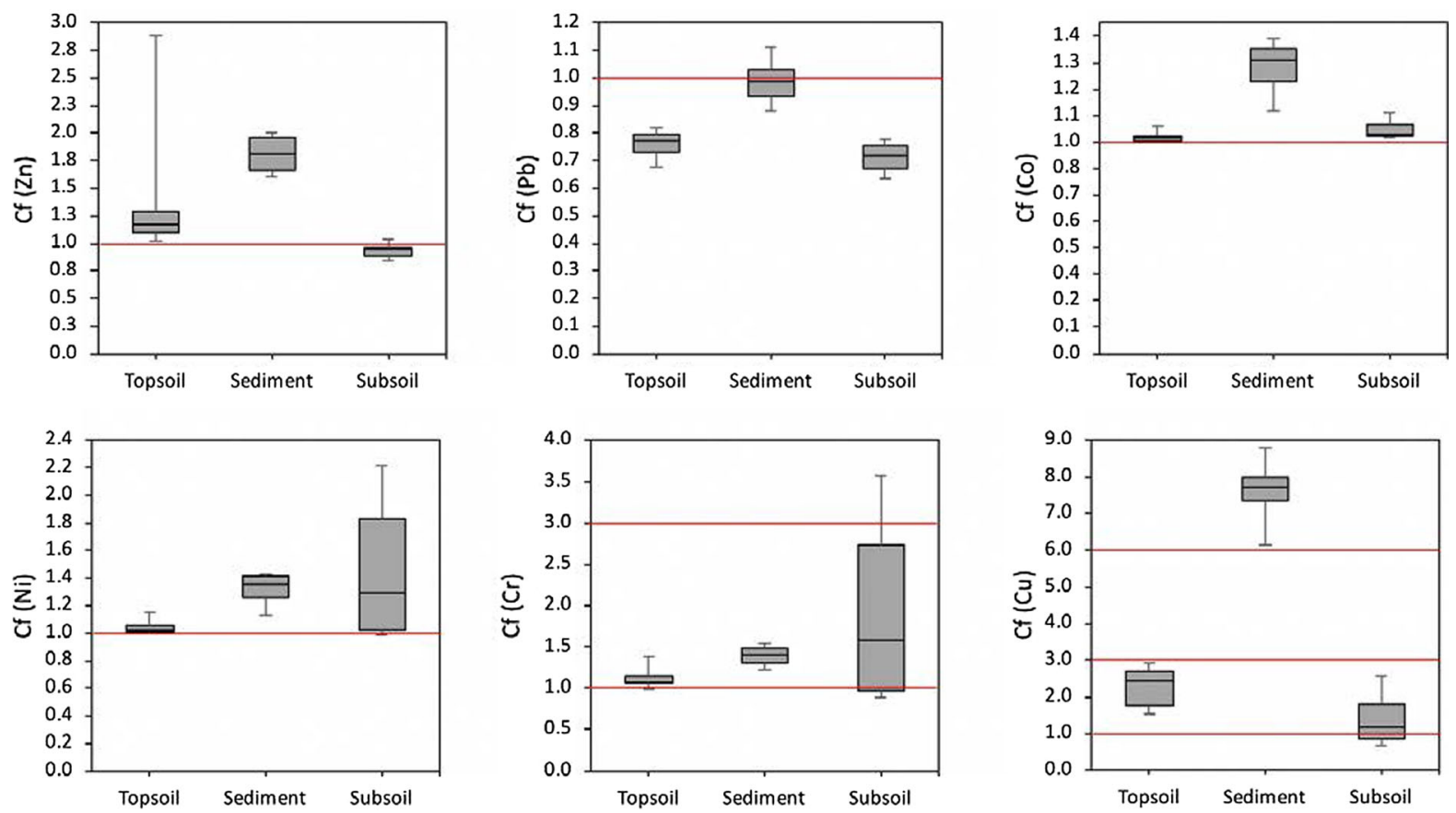

Fig. 4 Contamination factor (Cf) of PTEs in the top- $(0-20 \mathrm{~cm})$ and subsoil $(>20 \mathrm{~cm})$ and sediments. The red lines highlight $\mathrm{Cf}=1$, above which contamination is identified; $\mathrm{Cf}=3$, above which considerable contamination is identified; $\mathrm{Cf}=6$, above which high contamination is identified 
for $\mathrm{Cu}$ (ranging from 6.2 to 8.8 ) indicate significant contamination and strong enrichment of $\mathrm{Cu}$ compared to the local forest soil. In general, moderate contamination was observed for all examined PTEs in the vineyard top- and subsoil, except for $\mathrm{Pb}$.

The calculated contamination indices showed that $\mathrm{Cu}, \mathrm{Zn}, \mathrm{Ni}$, and $\mathrm{Cr}$ predominantly accumulated in the studied vineyard soils and were significantly enriched in the eroded sediments, causing an elevated pollution risk, in particular, for $\mathrm{Cu}$. The pollution load index (PLI) encompassing all individual $\mathrm{Cf}$ values varied from 1.01 to 1.42 and from 0.84 to 1.39 for vineyard top- and subsoils, respectively, classifying the vineyard soils in no to moderate pollution status. Meanwhile, the higher PLI for the eroded sediments, ranging from 1.55 to 1.98 (Fig. 5), belongs to the moderate pollution category. Significant contamination is detected when the PLI value exceeds 1 (Rinklebe et al., 2019), demonstrating that the studied vineyard soils and sediments represent a multielement contamination case.

\section{Ecological risk assessment}

Former studies identified the ecological risk index (ERI) as one of the most powerful indices for assessing the overall ecological risk in soils and sediments (Arfaeinia et al., 2019; Luo et al., 2007; Liu et al., 2014). Based on the ecological risk indices (Ei) summarized in Table 5, the soil and eroded sediments represent a low ecological risk. Indeed, all calculated values are below the ecological risk thresholds of 40 for Ei and 90 for ERI. The ecological risk indices

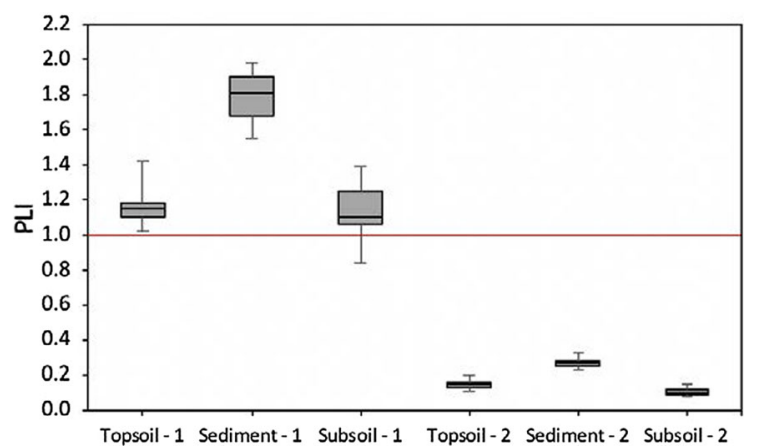

Fig. 5 The pollution load index (PLI) of the top- $(0-20 \mathrm{~cm})$, subsoil $(>20 \mathrm{~cm})$, and sediments in the studied vineyard (1calculated with the total PTEs; 2-calculated with EDTA extracted PTEs). The red line displays PLI $=1$, above which pollution is identified
Table 5 The average values of the ecological risk indices for target PTEs in the top- $(0-20 \mathrm{~cm})$ and subsoil $(>20 \mathrm{~cm})$ and eroded sediments (EDTA extracted PTE contents are marked with $\mathrm{X}_{\mathrm{E}}$ ). Ei stands for the ecological risk factor, while ERI is the ecological risk index

\begin{tabular}{lccc}
\hline & Ei (Topsoil) & Ei (Sediment) & Ei (Subsoil) \\
\hline \multicolumn{2}{l}{ Pseudo-total metals } & & \\
$\mathrm{Zn}$ & 1.3 & 1.8 & 0.9 \\
$\mathrm{~Pb}$ & 3.8 & 4.9 & 3.6 \\
$\mathrm{Co}$ & 4.9 & 6.5 & 5.1 \\
$\mathrm{Ni}$ & 6.2 & 7.9 & 8.7 \\
$\mathrm{Cr}$ & 2.2 & 2.8 & 3.8 \\
$\mathrm{Cu}$ & 11.3 & 38.0 & 7.0 \\
$\mathrm{ERI}$ & 29.8 & 62.0 & 29.2 \\
EDTA & extracted metals & & \\
$\mathrm{Zn}_{\mathrm{E}}$ & 0.2 & 0.4 & 0.0 \\
$\mathrm{~Pb}_{\mathrm{E}}$ & 1.6 & 3.2 & 1.7 \\
$\mathrm{Co}_{\mathrm{E}}$ & 1.9 & 1.4 & 2.3 \\
$\mathrm{Ni}_{\mathrm{E}}$ & 0.6 & 0.5 & 0.9 \\
$\mathrm{Cr}_{\mathrm{E}}$ & 0.0 & 0.0 & 0.0 \\
$\mathrm{Cu}_{\mathrm{E}}$ & 4.9 & 24.6 & 2.2 \\
$\mathrm{ERI}_{\mathrm{E}}$ & 9.2 & 30.2 & 7.1 \\
\hline
\end{tabular}

showed no elevated ecological risk in the studied organic vineyard; meanwhile, Mirzaei and co-workers (2019) reported the range of ERI (for $\mathrm{Cu}, \mathrm{Zn}, \mathrm{Pb}, \mathrm{Cr}$, and $\mathrm{Cd}$ ) in 38 long-term fertilized vineyards from 5.30 to 468.09 , indicating considerable ecological risk for 6 vineyards representing a moderate risk and 3 vineyards a high risk. Considering bioavailable PTE contents for the ecological risk assessment (Table 5), which depict an even more realistic estimation of environmental threats, the calculated indices are lower and show a negligible risk.

As expected from the Ei data for the target PTEs, the two highest contributors to the ERI were $\mathrm{Cu}(\mathrm{Ei}$ (average): 11.3 in the topsoil, 38.0 in the sediment, and 7.0 in the subsoil), followed by $\mathrm{Ni}$ (6.2 in the topsoil, 7.9 in the sediment, and 8.7 in the subsoil). The relative contribution to the overall ecological risk of the other examined PTEs was negligible. The highest values of Ei were assessed for $\mathrm{Cu}$, especially in eroded sediments $(\mathrm{Ei}$ (pseudo-total $\mathrm{Cu})=38.0$, accounting for $61.3 \%$ of the total ecological risk). The disparity was noticeable for the bioavailable fraction of $\mathrm{Cu}$ in the vineyard soil and sediment. The figures for 
bioavailable $\mathrm{Cu}$ contribution to the ERI in eroded sediments reached its maximum Ei of 24.6 and made up $82 \%$ of the total ecological risk. The latter revealed the prevailing influence of bioavailable $\mathrm{Cu}$ in the overall ecological risk represented by the six target PTEs in the vineyard. In addition, the most noticeable difference between the distribution percentage of pseudo-total and bioavailable $\mathrm{Cu}$ relative to the total ERI indicated an apparent increase in the ecological risk prevailing in the sediments, especially for the EDTA extracted fractions.

\section{Conclusions}

Cultivation in steep areas such as sloping vineyards exerts a significant impact on the soil environment and affects the spatial distribution of potentially toxic elements. Soil erosion and the long-term use of chemical fertilizers, fungicides, and organic byproducts can raise the pollution and ecological risk related to potentially toxic elements (PTEs) in vineyards. The soil and eroded sediments demonstrated a multielement contamination case in the organic vineyard with PLI exceeding 1. Significant enrichment was apparent for pseudo-total contents of $\mathrm{Cu}$ in the topsoil attributed to $\mathrm{Cu}$-based fungicides' use. Differently, $\mathrm{Ni}$ and $\mathrm{Cr}$ showed a noticeable accumulation in the subsoil (originated predominantly from geogenic sources or manure applications), displaying a moderate contamination level. Consequently, a potential risk of toxicity may arise, especially in the rhizosphere area.

On the other hand, the target PTEs tented to enrich significantly in the eroded sediments. Copper exhibited higher contents in the sediments (148.1-211.5 mg/kg) compared to those in the vineyard topsoil (range: $36.5-70.0 \mathrm{mg} / \mathrm{kg}$ ). Accordingly, the highest ER was also determined for $\mathrm{Cu}(\mathrm{ER}>3)$, revealing its marked enrichment. Contamination factors also showed significant $\mathrm{Cu}$ pollution compared to the reference neighboring forest soil. Despite high pseudo-total $\mathrm{Cu}$ contents in the soil, the pollution threshold was not exceeded according to Hungarian national standards. A moderate enrichment of $\mathrm{Zn}$ was also observed in the vineyard topsoil compared to the subsoil, likely due to inputs through micronutrient fertilizer applications.
The examined PTEs demonstrated higher bioavailable contents in the eroded sediments than the top-and subsoil, except $\mathrm{Ni}$ and $\mathrm{Cr}$. The predominant bioavailable nature of $\mathrm{Cu}$ in the sediment samples $(63 \%$ of pseudo-total $\mathrm{Cu}$ ) revealed a plausible ecological risk. Although high bioavailability ratios of $\mathrm{Pb}$ and $\mathrm{Co}$ in the soil and sediments indicated their lability in the vineyard, soil pollution by $\mathrm{Pb}$ and $\mathrm{Co}$ was not evidenced. Zinc was moderately bioavailable, while $\mathrm{Ni}$ and $\mathrm{Cr}$ were immobile with bioavailable ratios less than $9 \%$ and $1 \%$, respectively.

Ecological risk assessment based on the pseudototal and bioavailable contents of PTEs showed a low risk $(E R I<90)$ in the studied vineyard. Copper was the dominating risk factor regardless of its forms (total and bioavailability) in the entire ecological risk. The high bioavailable $\mathrm{Cu}$ contents in eroded sediments accounted for up to $82 \%$ of the total ecological risk by all examined PTEs. The latter revealed an apparent risk induced by the high lability of $\mathrm{Cu}$ in the runofftransported sediments, which is expected to increase over time with the repeated use of $\mathrm{Cu}$-based agrochemicals.

Acknowledgements Nhung Thi Ha Pham would like to thank the Tempus Public Foundation (TPF)-Stipendium Hungaricum program for providing her $\mathrm{PhD}$ scholarship. Izabella Babcsányi is grateful for the support of the Premium Postdoctoral Research Program of the Hungarian Academy of Sciences.

Funding Open access funding provided by University of Szeged. The work received financial support from the Premium Postdoctoral Research Program of the Hungarian Academy of Sciences and the OTKA $1 \mathrm{~K} 116981$ projects.

Open Access This article is licensed under a Creative Commons Attribution 4.0 International License, which permits use, sharing, adaptation, distribution and reproduction in any medium or format, as long as you give appropriate credit to the original author(s) and the source, provide a link to the Creative Commons licence, and indicate if changes were made. The images or other third party material in this article are included in the article's Creative Commons licence, unless indicated otherwise in a credit line to the material. If material is not included in the article's Creative Commons licence and your intended use is not permitted by statutory regulation or exceeds the permitted use, you will need to obtain permission directly from the copyright holder. To view a copy of this licence, visit http://creativecommons.org/licenses/by/4.0/. 


\section{References}

Antoniadis, V., Shaheen, S. M., Boersch, J., Frohne, T., Du Laing, G., \& Rinklebe, J. (2017a). Bioavailability and risk assessment of potentially toxic elements in garden edible vegetables and soils around a highly contaminated former mining area in Germany. Journal of Environmental Management, 186, 192-200. https://doi.org/10.1016/j.jenvman. 2016.04.036

Antoniadis, V., Golia, E. E., Shaheen, S. M., \& Rinklebe, J. (2017b). Bioavailability and health risk assessment of potentially toxic elements in Thriasio Plain, near Athens Greece. Environmental Geochemistry and Health, 39(2), 319-330. https://doi.org/10.1007/s10653-016-9882-5

Antoniadis, V., Golia, E. E., Liu, Y.-T., Wang, S.-L., Shaheen, S. M., \& Rinklebe, J. (2019). Soil and maize contamination by trace elements and associated health risk assessment in the industrial area of Volos, Greece. Environment International, 124, 79-88. https://doi.org/10.1016/j.envint. 2018.12.053

Alibrahim, Z. O., \& Williams, C. D. (2016). Assessment of bioavailability of some potential toxic metals in miningaffected soils using EDTA extraction and principle component analysis (PCA) approach, Derbyshire UK. Interdiscipilinary Journal of Chemistry, 1(2), 58-65. https://doi. org/10.15761/IJC.1000110

Arfaeinia, H., Dobaradaran, S., Moradi, M., Pasalari, H., Mehrizi, E. A., Taghizadeh, F., Esmaili, A., \& Ansarizadeh, M. (2019). The effect of land use configurations on concentration, spatial distribution, and ecological risk of heavy metals in coastal sediments of northern part along the Persian Gulf. The Science of the Total Environment, 653, 783-791. https://doi.org/10.1016/j.scitotenv.2018.11.009

Babcsányi, I., Chabaux, F., Granet, M., Meite, F., Payraudeau, S., Duplay, J., \& Imfeld, G. (2016). Copper in soil fractions and runoff in a vineyard catchment: Insights from copper stable isotopes. The Science of the Total Environment, 557-558, 154-162. https://doi.org/10.1016/j.scitotenv. 2016.03.037

Ballabio, C., Panagos, P., Lugato, E., Huang, J., Orgiazzi, A., Jones, A., Fernández-Ugalde, O., Borrelli, P., \& Montanarella, L. (2018). Copper distribution in European topsoils: An assessment based on LUCAS soil survey. The Science of the Total Environment, 636, 282-298.

Barakat, M. A., Ismail, S. M., \& Ehsan, M. (2016). Immobilization of $\mathrm{Ni}$ and $\mathrm{Zn}$ in soil by cow and chicken manure. International Journal of Waste Resources, 6, 228. https:// doi.org/10.4172/2252-5211.1000228

Barrio-Parra, F., Elío, J., De Miguel, E., García-González, J. E., Izquierdo, M., \& Álvarez, R. (2017). Environmental risk assessment of cobalt and manganese from industrial sources in an estuarine system. Environmental Geochemistry and Health, 40(2), 737-748. https://doi.org/10.1007/ s10653-017-0020-9

Berlanas, C., Berbegal, M., Elena, G., Laidani, M., Cibriain, J. F., Sagües, A., \& Gramaje, D. (2019). The fungal and bacterial rhizosphere microbiome associated with grapevine rootstock genotypes in mature and young vineyards. Frontiers in Microbiology. https://doi.org/10.3389/fmicb. 2019.01142
Besnard, E., Chenu, C., \& Robert, M. (2001). Influence of organic amendments on copper distribution among particle-size and density fractions in Champagne vineyard soils. Environmental Pollution, 112(3), 329-337. https://doi.org/ 10.1016/s0269-7491(00)00151-2

Biddoccu, M., Guzmán, G., Capello, G., Thielke, T., Strauss, P., Winter, S., \& Gómez, J. A. (2020). Evalu-ation of soil erosion risk and identification of soil cover and management factor (C) for RUSLE in European vineyards with different soil manage-ment. International Soil and Water Conservation Research, 8(4), 337-353.

Biddoccu, M., Ferraris, S., Opsi, F., \& Cavallo, E. (2016). Longterm monitoring of soil management effects on runoff and soil erosion in sloping vineyards in Alto Monferrato (North-West Italy). Soil and Tillage Research, 155, 176-189. https://doi.org/10.1016/j.still.2015.07.005

Biswas, B., Qi, F., Biswas, J., Wijayawardena, A., Khan, M., \& Naidu, R. (2018). The fate of chemical pollutants with soil properties and processes in the climate change paradigma review. Soil Systems, 2(3), 51. https://doi.org/10.3390/ soilsystems 2030051

Bojar, H.-P., Antoniade, C., Barbu, V., \& Bojar, A.-V. (2020). A new preparation method of microfauna from gypsum: micropaleontological association from the middle miocene badenian gypsum deposits of paratethys. Geosciences, 10(5), 158. https://doi.org/10.3390/geosciences 10050158

Borgese, L., Federici, S., Zacco, A., Gianoncelli, A., Rizzo, L., Smith, D. R., \&... Bontempi, E. (2013). Metal fractionation in soils and assessment of environmental contamination in Vallecamonica. Italy. Environmental Science and Pollution Research, 20(7), 5067-5075. https://doi.org/10.1007/ s11356-013-1473-8

Bradl, H. B. (2004). Adsorption of heavy metal ions on soils and soils constituents. Journal of Colloid and Interface Science, 277, 1-18.

Brunetto, G., Bastos de Melo, G. W., Terzano, R., Del Buono, D., Astolfi, S., Tomasi, N., \&... Cesco, S. (2016). Copper accumulation in vineyard soils: Rhizosphere processes and agronomic practices to limit its toxicity. Chemosphere, 162, 293-307. https://doi.org/10.1016/j.chemosphere. 2016.07.104

Brunetto, G., Miotto, A., Ceretta, C. A., Schmitt, D. E., Heinzen, J., de Moraes, M. P., \& Girotto, E. (2014). Mobility of copper and zinc fractions in fungicide-amended vineyard sandy soils. Archives of Agronomy and Soil Science, 60(5), 609-624. https://doi.org/10.1080/03650340.2013.826348

Canuto, F. A. B., Garcia, C. A. B., Alves, J. P. H., \& Passos, E. A. (2013). Mobility and ecological risk assessment of trace metals in polluted estuarine sediments using a sequential extraction scheme. Environmental Monitoring and Assessment, 185, 6173-6185.

Carter, M., \& Gregorich, E. (2007). Soil sampling and methods of analysis chapter 10 - trace element assessment. Boca Raton: CRC Press.

Chen, H. Y., Teng, Y. G., Lu, S. J., Wang, Y. Y., \& Wang, J. S. (2015). Contamination features and health risk of soil heavy metals in China. Science of the Total Environment, 512-513, 143-153.

Chevigny, E., Quiquerez, A., Petit, C., \& Curmi, P. (2014). Lithology, landscape structure and management practice changes: Key factors patterning vineyard soil erosion at 
metre-scale spatial resolution. CATENA, 121, 354-364. https://doi.org/10.1016/j.catena.2014.05.022

Czigány, S., Novák, T. J., Pirkhoffer, E., Nagy, G., Lóczy, D., Dezső, J., Ákos Fábián, S., Świtoniak, M., \& Charzyński, P. (2020). Application of a topographic pedosequence in the Villány Hills for terroir characterization. Hungarian Geographical Bulletin, 69(3), 245-261. https://doi.org/10. 15201/hungeobull.69.3.2

Devi, U., \& Bhattacharyya, K. G. (2018). Mobility and bioavailability of $\mathrm{Cd} \mathrm{Co}, \mathrm{Cr}, \mathrm{Cu}, \mathrm{Mn}$ and $\mathrm{Zn}$ in surface runoff sediments in the urban catchment area of Guwahati India. Applied Water Science, 8, 18. https://doi.org/10. 1007/s13201-018-0651-8

Dhaliwal, S. S., Naresh, R. K., Mandal, A., Singh, R., \& Dhaliwal, M. K. (2019). Dynamics and transformations of micronutrients in agricultural soils as influenced by organic matter build-up: A review. Environmental and Sustainability Indicators, 1-2, 100007. https://doi.org/10.1016/j. indic.2019.100007

Dövényi Z., Becse A., Mezősi G., Ádám L., Juhász Á., Marosi S., Somogyi S., Szilárd J., Ambrózy P., Konkolyné Bihari Z., Király G., Molnár Zs., Bölöni J., Csiky J., Vojtkó A., Rajkai K., Tóth G., Tiner T., Michalkó G., and Keresztesi Z. (2010). Magyarország kistájainak katasztere. (Inventory of Microregions in Hungary) 2nd edition, MTA Földrajztudományi Kutatóintézet, Budapest. (in Hungarian)

Duplay, J., Semhi, K., Errais, E., Imfeld, G., Babcsanyi, I., \& Perrone, T. (2014). Copper, zinc, lead and cadmium bioavailability and retention in vineyard soils (Rouffach, France): The impact of cultural practices. Geoderma, 230, 318-328. https://doi.org/10.1016/j.geoderma.2014.04.022

Farsang, A., Kitka, G., Barta, K., \& Puskás, I. (2012). Estimating element transport rates on sloping agricultural land at catchment scale (Velence Mts, NW Hungary) Carpathian. Journal of earth and Environmental Sciences, 7(4), 15-26.

Farsang, A., \& Barta, K. (2004). A talajerózió hatása a feltalaj makro- és mikroelem tartalmára (The effect of soil erosion on the macro- and microelement content of the topsoil). Talajvédelem (Soil Protection), 2004(1), 268-276.

Fernández-Calviño, D., Pateiro-Moure, M., Nóvoa-Muñoz, J. C., Garrido-Rodríguez, B., \& Arias-Estévez, M. (2012). Zinc distribution and acid-base mobilisation in vineyard soils and sediments. Science of the Total Environment, 414, 470-479. https://doi.org/10.1016/j.scitotenv.2011.10.033

Fernández-Calviño, D., Pateiro-Moure, M., López-Períago, E., Arias-Estévez, M., \& Nóvoa-Muñoz, J. C. (2008). Copper distribution and acid-base mobilization in vineyard soils and sediments from Galicia (NW Spain). European Journal of Soil Science, 59, 315-326. https://doi.org/10.1111/j. 1365-2389.2007.01004.x

Ferretti, C. G. (2019). Relationship between the geology, soil assessment, and terroir of Gewürtztraminer vineyards: A case study in the Dolomites of northern Italy. CATENA, 179, 74-84. https://doi.org/10.1016/j.catena.2019.03.044

Gong, Q., Chen, P., Shi, R., Gao, Y., Zheng, S.-A., Xu, Y., \&... Zheng, X. (2019). Health assessment of trace metal concentrations in organic fertilizer in Northern China. International Journal of Environmental Research and Public Health, 16(6), 1031. https://doi.org/10.3390/ ijerph 16061031
Grove, T. L., Baker, M. B., Price, R. C., Parman, S. W., ElkinsTanton, L. T., Chatterjee, N., \& Muntener, O. (2004). Magnesian andesite and dacite lavas from Mt. Shasta, northern California: Products of fractional crystallization of H2O-rich mantle melts. Contributions to Mineralogy and Petrology, 148(5), 542-565. https://doi.org/10.1007/ s00410-004-0619-6

Hakanson, L. (1980). An ecological risk index for aquatic pollution control. A sedimentological approach. Water Research, 14(8), 975-1001. https://doi.org/10.1016/00431354(80)90143-8

Harangi, S., and Lenkey, L., 2007, Genesis of the Neogene to Quaternary volcanism in the Carpathian-Pannonian region: Role of subduction, extension, and mantle plume, in Beccaluva, L., Bianchini, G., and Wilson, M., eds., Cenozoic Volcanism in the Mediterranean Area: Geological Society of America Special Paper 418: 67-92. doi: https://doi.org/ 10.1130/2007.2418(04).

He, Z. L., Zang, M. K., Calvert, D. V., Stoffella, P. J., Yang, X. E., \& Yu, S. (2004). Transport of heavy metals in surface runoff from vegetable and citrus fields. Soil Science Society of America Journal, 68, 1662-1669.

Islam, M. S., Ahmed, M. K., \& Habibullah-Al-Mamun, M. (2015). Metal speciation in soil and health risk due to vegetables consumption in Bangladesh. Environmental Monitoring and Assessment. https://doi.org/10.1007/ s10661-015-4533-3

IUSS Working Group WRB (2015). World Reference Base for Soil Resources 2014, update 2015 International soil classification system for naming soils and creating legends for soil maps. World Soil Resources Reports No. 106. FAO, Rome.

Joint Decree No. 6/2009. (IV. 14) KvVM-EüM-FVM of the Ministers of Environmental Protection and Water Management, Public Health, Agriculture and Regional Development on the Limit Values Necessary to Protect the Quality of Geological Medium and the Groundwater and on Measurement of Pollution.

Kashem, M., \& Singh, B. (2001). Metal availability in contaminated soils: II. Uptake of $\mathrm{Cd}, \mathrm{Ni}$ and $\mathrm{Zn}$ in rice plants grown under flooded culture with organic matter addition. Nutrient Cycling in Agroecosystems, 61, 257-266.

Kerényi, A. (1994). Loess erosion on the Tokaj Big-Hill. Quaternary International, 24, 47-52.

Komárek, M., Čadková, E., Chrastný, V., Bordas, F., \& Bollinger, J.-C. (2010). Contamination of vineyard soils with fungicides: A review of environmental and toxicological aspects. Environment International, 36(1), 138-151. https://doi.org/10.1016/j.envint.2009.10.005

Kosmas, C., Danalatos, N., Cammeraat, L. H., Chabart, M., Diamantopoulos, J., Farand, R., et al. (1997). The effect of land use on runoff and soil erosion rates under Mediterranean conditions. CATENA, 29, 45-59.

Koulouri, M., \& Giourga, C. (2007). Land abandonment and slope gradient as key factors of soil erosion in Mediterranean terraced lands. CATENA, 69, 274-281.

Lago-Vila, M., Arenas-Lago, D., Rodríguez-Seijo, A., Andrade Couce, M. L., \& Vega, F. A. (2015). Cobalt, chromium and nickel contents in soils and plants from a serpentinite quarry. Solid Earth, 6, 323-335. https://doi.org/10.5194/ se-6-323-2015 
Li, J., \& Zhou, Z. X. (2015). Natural and human impacts on ecosystem services in Guanzhong - Tianshui economic region of China. Environmental Science and Pollution Research, 23(7), 6803-6815. https://doi.org/10.1007/ s11356-015-5867-7

Li, N., Kang, Y., Pan, W., Zeng, L., Zhang, Q., \& Luo, J. (2015). Concentration and transportation of heavy metals in vegetables and risk assessment of human exposure to bioaccessible heavy metals in soil near a waste-incinerator site, South China. Science of the Total Environment, 521-522, 144-151. https://doi.org/10.1016/j.scitotenv.2015.03.081

Liang, Q., Xue, Z. J., Wang, F., Sun, Z. M., Yang, Z. X., \& Liu, S. Q. (2015). Contamination and health risks from heavy metals in cultivated soil in Zhangjiakou City of Hebei province China. Environmental Monitoring and Assessment, 187(12), 754.

Liu, W., Zhao, J., Ouyang, Z., Söderlund, L., \& Liu, G. (2005). Impacts of sewage irrigation on heavy metal distribution and contamination in Beijing China. Environment International, 31(6), 805-812. https://doi.org/10.1016/j.envint. 2005.05.042

Liu, G., Yu, Y., Hou, J., Xue, W., Liu, X., Liu, Y., et al. (2014). An ecological risk assessment of heavy metal pollution of the agricultural ecosystem near a lead-acid battery factory. Ecological Indicators, 47, 210-218.

Lóczy, D. (2015). Landscapes and landforms of Hungary part II. landscapes and landforms. Switzerland: Springer International Publishing.

Luo, W., Lu, Y., Giesy, J. P., Wang, T., Shi, Y., Wang, G., et al. (2007). Effects of land use on concentrations of metals in surface soils and ecological risk around Guanting Reservoir. China. Environmental Geochemistry and Health, 29(6), 459-471.

Manaljav, S., Farsang, A., Barta, K., Tobak, Z., Juhász, S., Balling, P., \& Babcsányi, I. (2021). The impact of soil erosion on the spatial distribution of soil characteristics and potentially toxic element contents in a sloping Vineyard in Tállya Ne Hungary. Journal of Environmental Geography, 14(1-2), 47-57. https://doi.org/10.2478/jengeo-2021-0005

Martínez-Casasnovas, J. A., \& Ramos, M. C. (2006). The cost of soil erosion in vineyard fields in the Penede' s-Anoia Region (NE Spain). CATENA, 68, 194-199.

McBride, M., Martínez, C. E., \& Sauvé, S. (1998). Copper(II) activity in aged suspensions of goethite and organic matter. Soil Science Society of America Journal, 62(6), 1542. https://doi.org/10.2136/sssaj1998.0361599500620006001

Milićević, T., Urošević, M. A., Relić, D., Vuković, G., Škrivanj, S., \& Popović, A. (2018). Bioavailability of potentially toxic elements in soil-grapevine (leaf, skin, pulp and seed) system and environmental and health risk assessment. Science of the Total Environment, 626, 528-545. https:// doi.org/10.1016/j.scitotenv.2018.01.094

Ministry of the Environment, Finland, 2007. Government Decree on the Assessment of Soil Contamination and Remediation Needs (214/2007, March 1, 2007).

Mirlean, N., Roisenberg, A., \& Chies, J.O. (2007). Metal contamination of vineyard soils in wet subtropics (southern Brazil). Environmental pollution, 149(1), 10-7. https://doi. org/10.1016/j.envpol.2006.12.024

Mirzaei, M., Marofi, S., Solgi, E., Abbasi, M., Karimi, R., \& Riyahi Bakhtyari, H. R. (2019). Ecological and health risks of soil and grape heavy metals in long-term fertilized vineyards (Chaharmahal and Bakhtiari province of Iran). Environmental Geochemistry and Health. https://doi.org/ 10.1007/s10653-019-00242-5

Molnár, F., Nagymarosy, A., Jeleň, S., \& Bačo, P. (2010). Minerals and wines: Tokaj Mts., Hungary and Slanské vrchy Mts Slovakia. Acta Mineral-Petrograph Field Guide Series, 15, 1-40.

MSZ-08-0205, 1978. Determination of Physical and Hydrophysical Properties of Soils. Hungarian Standard Association, Budapest (in Hungarian).

MSZ-08-0206-2, 1978. Evaluation of Some Chemical Properties of the Soil. Laboratory Tests. (pH Value, Phenolphtaleine Alkalinity Expressed in Soda, All Water Soluble Salts, Hydrolite (y1-Value) and Exchanging Acidity (y2Value)). Hungarian Standard Association, Budapest (in Hungarian).

MSZ 21470-52, 1983. Environmental Protection. Testing of Soils. Determination of Organic Matter. Hungarian Standard Association, Budapest (in Hungarian).

Novara, A., Gristina, L., Saladino, S. S., Santoro, A., \& Cerdà, A. (2011). Soil erosion assessment on tillage and alternative soil managements in a Sicilian vineyard. Soil and Tillage Research, 117, 140-147. https://doi.org/10.1016/j. still.2011.09.007

Novák, T. J., Incze, J., Spohn, M., Glina, B., \& Giani, L. (2014). Soil and vegetation transformation in abandoned vineyards of the Tokaj Nagy-Hill, Hungary. CATENA, 123, 88-98. https://doi.org/10.1016/j.catena.2014.07.017

Nunes, J., Ramos-Miras, J., Lopez-Piñeiro, A., Loures, L., Gil, C., Coelho, J., \& Loures, A. (2014). Concentrations of available heavy metals in mediterranean agricultural soils and their relation with some soil selected properties: A case study in typical mediterranean soils. Sustainability, 6(12), 9124-9138. https://doi.org/10.3390/su6129124

Pham, N. T.H., Babcányi, I., Balling, P., Farsang, A., Accumulation Patterns and Health Risk Assessment of Potentially Toxic Elements in The Topsoil of Two Sloping Vineyards (Tokaj-Hegyalja, Hungary). (Forthcoming paper).

Preston, W., da Silva, Y. J. A. B., do Nascimento, C. W. A., da Cunha, K. P. V., Silva, D. J., \& Ferreira, H. A. (2016). Soil contamination by heavy metals in vineyard of a semiarid region: An approach using multivariate analysis. Geoderma Regional, 7, 357-365. https://doi.org/10.1016/j. geodrs.2016.11.002

Qi, Y., Wang, R., Qin, Q., \& Sun, Q. (2019). Soil affected the variations in grape and wine properties along the eastern foot of Helan Mountain China. Acta Agriculturae Scandinavica, Section B Soil Plant Science. https://doi.org/10. 1080/09064710.2019.1611914

Ribolzi, O., Valles, V., Gomez, L., \& Voltz, M. (2002). Speciation and origin of particulate copper in runoff water from a Mediterranean vineyard catchment. Environmental Pollution, 117(2), 261-271. https://doi.org/10.1016/s02697491(01)00274-3

Rinklebe, J., Antoniadis, V., Shaheen, S. M., Rosche, O., \& Altermann, M. (2019). Health risk assessment of potentially toxic elements in soils along the Central Elbe River, Germany. Environment International, 126, 76-88. https:// doi.org/10.1016/j.envint.2019.02.011 
Rinklebe, J., \& Shaheen, S. M. (2014). Assessing the Mobilization of Cadmium, Lead, and Nickel Using a Seven-Step Sequential Extraction technique in contaminated floodplain soil profiles along the central Elbe River Germany. Water, Air, \& Soil Pollution. https://doi.org/10.1007/ s11270-014-2039-1

Romić, M., Romić, D., Dolanjski, D., \& Stricevic, I. (2004). Heavy metals accumulation in topsoils from the winegrowing regions. Agriculturae Conspectus Scientificus, 69(1), 1-10.

Schaller, L., Targetti, S., Villanueva, A. J., Zasada, I., Kantelhardt, J., Arriaza, M., \&... Viaggi, D. (2018). Agricultural landscapes, ecosystem services and regional competitiveness - Assessing drivers and mechanisms in nine European case study areas. Land Use Policy, 76, 735-745. https://doi. org/10.1016/j.landusepol.2018.03.001

Scheinost, A. C. (2005). Metal Oxides. Encyclopedia of Soils in the Environment, 428-438. https://doi.org/10.1016/b0-12348530-4/00194-6

Shaheen, S. M., Shams, M. S., Khalifa, M. R., El-Dali, M. A., \& Rinklebe, J. (2017). Various soil amendments and environmental wastes affect the (im) mobilization and phytoavailability of potentially toxic elements in a sewage effluent irrigated sandy soil. Ecotoxicology and Environmental Safety, 142, 375-387. https://doi.org/10.1016/j. ecoenv.2017.04.026

Sipos, P. (2004). Geologic and pedogenic effects on heavy metal distributions in forest soils from the Cserhát Mts and the Karancs area. NE Hungary. Acta Geologica Hungarica, 47(4), 411-429.

SPSS Inc, (2009). PASW Statistic for Windows, Version 18.0. Released 2009. SPSS Inc, Chicago.

Sun, Y., Zhou, Q., Xie, X., \& Liu, R. (2010). Spatial, sources and risk assessment of heavy metal contamination of urban soils in typical regions of Shenyang China. Journal of Hazardous Materials, 174(1-3), 455-462.

Szepesi, J., Lukács, R., T. Biró, K., Markó, A, Pécskay, Z.\& Harangi, Sz., (2018). Geology of Tokaj Mountains obsidians, Archeometriai Mühely XV/3 167-180.

Szolnoki, Zs., \& Farsang, A. (2013). Evaluation of metal mobility and bioaccessibility in soils of urban vegetable gardens using sequential extraction. Water Air and Soil Pollution, 224, 1737. https://doi.org/10.1007/s11270013-1737-4

Toth, G., Hermann, T., Da Silva, M. R., \& Montanarella, L. (2016). Heavy metals in agricultural soils of the European Union with implications for food safety. Environment International, 88, 299-309. https://doi.org/10.1016/j. envint.2015.12.017

Udom, B. E., Omovbude, S., \& Abam, P. O. (2018). Topsoil removal and cultivation effects on structural and hydraulic properties. CATENA, 165, 100-105. https://doi.org/10. 1016/j.catena.2018.01.029

Violante, A., Cozzolino, V., Perelomov, L., Caporale, A., \& Pigna, M. (2010). Mobility and bioavailability of heavy metals and metalloids in soil environments. Journal of Soil Science and Plant Nutrition. https://doi.org/10.4067/ s0718-95162010000100005

Zelenka, T., Balázs, E., Balogh, K., Kiss, J., Kozák, M., Nemesi, L., Pécskay, Z., Püspöki, Z., Ravasz, C., Széky-Fux, V., \& Újfalussy, A. (2004). Buried Neogene volcanic structures in Hungary. Acta Geologica Hungarica, 47(2-3), 177-219.

Publisher's Note Springer Nature remains neutral with regard to jurisdictional claims in published maps and institutional affiliations. 